\title{
Evaluating Museum Service Experience Through Mobile Ethnography in The Perception of Generation $\mathrm{Z}$
}

\author{
Dini Anggraeni Sirad ${ }^{1 *}$ \\ ${ }^{1}$ Universitas Prasetiya Mulya \\ *dini.sirad@pmbs.ac.id
}

\begin{abstract}
A Museum management success factors have changed from previous display of conservation and historical information (Goulding, 1999) towards the integration of positive customer feedback and their perceived experiences of the entire visit. This paper suggests a mobile ethnography as a methodological basis for analyzing Gen $\mathrm{Z}$ visitor experience. The method is considered more appropriate as this generation is the first generation born into the world where physical aspects (peoples and places) have digital equivalents where for them the real world and the virtual world naturally overlap (Fairview Capital, 2017). The research used purposive sampling technique that involve Gen $Z$ as the active investigators. The research is conducted in four museums run by the Indonesian government in Jakarta. The result of this research shown critical points in three broad aspects of "Physical and Design", "Curatorial", and "Museum Services" that could be used to help museum management in attracting younger generation. The research also shown the unobstrusive and ease of use of mobile ethnography application in a qualiatative research.
\end{abstract}

Keywords: Gen Z, Mobile ethnography, Museum experience 


\section{A. Introduction}

Tourism is the fourth biggest contributor of Indonsia foreign exchange revenue, after crude palm oil, oil and gas, and coal ( Fardah, 2017). Tourism as an industry unlike the manufacturing industry is known, but the tourism industry is not independent and is more intangible, the tourism industry is also called an industry without a smokeless industry (Yoeti in Salam et al., 2018). Tourism can be used as a catalyst for development as it asborb a large proportion of working labor (Spillane, 1987). As an educational tool, tourism can help with the continuing learning and culturalization of Indonesia's heritage, history, and cultures. With a museum visit, tourists can learn diverse history and social culture heritage of Indonesia.. There have been studies concerning the behavior and interest of the previous generations (e.g. Baby Boomers, Gen X, etc.), but there is a lack of research on the Generation $\mathrm{Z}$ or the digital native generation (Prensky,2001). In 2020s, Generation Z together with the Generation Y is predicted to be the most active players in the tourism market (Salvatore Monaco, 2018). For Indonesia's tourism sector to flourish, Measuring Gen $Z$ visitors' experience are becoming more essentials for the tourism sector. The purpose of this research is to examine Gen $\mathrm{Z}$ experience in the museum setting. Museums, particularly larger museums in major cities, are important as tourism destinations. They help to create a sense of place, contribute to the overall self-image of a destination, and are contributors to the tourism economy (Carey, Davidson, \& Sahli, 2013; Kirshenblatt-Gimblett, 1998; Stylianou-Lambert, 2011). Furthermore, many tourists visit museums in order to orient themselves to a destination's cultural identity (Stylianou-Lambert, 2011).

\section{B. Literature Review}

Every generation has its own uniqueness in consumption and production of culture. The generation theory tries to reveal each generation patterns by understanding their behavior. The previous generation such as Baby Boomers and Generation $Y$ had been the subject of investigation for some years, but there is still little attention in regards to Generation Z or Gen Z. Gen Z are those born after 1997. In the near future, this generation will be the target employees and consumers., especially The International Council of Museums (ICOM) define museum as a non-profit, permanent institution in the service of society and its development, open to the public, which acquires, conserves, researches, communicates and exhibits the tangible and intangible heritage of humanity and its environment for the purposes of education, study and enjoyment (ICOM, 2007).

Museums' initial purpose of conservation and presentation of historical information needs to be extended to include a deeper understanding of visitor experience via their personal thoughts and feelings during museum visits. Museum experience management views a museum as an amalgam of a series of experience encounters (tangible and intangible) that derives from both service 
providers (quality of performance) and visitor themselves (quality of experience) ( Muscat et al, 2013).

Museum experience is the result from both service providers and their visitors. To be relevant, museum needs to constantly change their objectives and priorities by understanding and evaluating the relationship with their audiences (Gilmore and Rentschler, 2002).

Quality of the experience has become more and more important for customers and regarded as a crucial factor for the profit, growth, customer satisfaction and customer loyalty. Managers and marketers should be more concerned on the quality of the experience and work on experience design and improvement with their customers (Andrades and Dimanche, 2014). The quality of visitor experience at the museum should be a main concern for museum management and development, as it is detrimental to visitors' destination experience vis-à-vis their loyalty and Museum's operational funding.

\section{Research Methodology}

This research utilizes mobile ethnography method to examine visitor's experience in a museum.

As mobile devices have become omnipresent among visitors (Kesselring, 2015), Mobile ethnography uses technology-based devices, e.g. smart phones, instead of traditional ethnographic face-to-face inquiry.

Within tourism research, researchers are harnessing mobile ethnography to explore tourist and visitor experiences (Dimanche and Prayag, 2016; Stickdorn, Frischhut, and Schmid, 2014). Dimanche and Gibbs (2016, n. p.) note that benefits of this method are that we can collect data on the service delivery site, at the time of service delivery, and in an unobtrusive way. Mobile ethnography makes it possible to get direct in-time user information, following the principal ideas of user-centered design (Constantine and Lockwood, 2001). The respondents do not have to recall their experience.

\section{Participants}

Eligible participants for this study are young tourists, age 18 to 20 years old spread across four museums in Jakarta, Indonesia: Gedung Joang 45 Museum, The Formulation of Proclamation Text Museum, Ceramics Museum and The Puppet Museum.

\section{Instruments}

To measure visitors' experience in the museum, the study uses an App called Experience Fellow ( please check experiencefellow.com ). Particpants were asked to download the App onto their smart phones. Once downloaded, participants were tasked to identify service touchpoints, rate and provide comment on these touchpoints. The app also allows them to upload photos or videos to further describe their museum experience. Each participant eventually creates their own journey map. The touchpoints are rated on a 5-point Likert- 
scale (-2 for "very unsatisfied", -1 for "satisfied", 0 for "neutral, +1 for "satistified" and +2 for "very unsatisfied").

\section{Data Analysis}

All the information given by the participants are recorded and processed in the "Experience Fellow" server. The researcher then grouped the different touchpoints, based on their given ratings. Afterwards, the researcher reviewed the comments from each touchpoint, then further analyzed the data to see the informants' critical touchpoints. From there, researcher synthesized all points of interest and annoying experiences of Gen $Z$ visitors.

\section{Result}

\subsection{Gedung Joang 45}

Mobile ethnographic results from Gedung Joang 45 indicated 95 touch points in 10 journeys. Overall respondents gave positive feedback about their experience at the museum. Gedung Joang 45 received 65-"Very Satisfied" touchpoints with only 1 - "Very Unsatisfied" touchpoints. The remainders are 28 - "Satisfied" and 1- "Unsatisfied".

The participants gave "Very Satisfied" rating on the museum's (1) Entrance room, with comments such as informative, clear, tidy and nice; (2) Ticket locket ; (3) Museums' collections, with comments such as unique, cute and amazed on the originality of the collection ; (4) Middle room with comments such, as elegant and tidy; (5) The Japanese Era room; (6) The Proclamation Room; (7) Toilet, as it is clean; (8) and museum's outdoor area with the classic cars.

Participants were "Satisfied" with the museum's (1) the locket booth, in which they considerd to be clean and tidy ; (2) middle room ; (3) the parking area; (4) The entrance and the façade; (5) The tour guide, who explained the museum's history and collections very well; (6) museum's original historical collections.

Participant gave one "Unsatisfied" touch point to a museum employee who asked the participants on what to see first. Table 1 shows Gedung Joang 45 Museum's touchpoints and keywords of its specific comments. 
Table 1. Touchpoints and Keywords of Gedung Joang 45 Museum

\begin{tabular}{|c|c|}
\hline Categories & Keywords \\
\hline $\begin{array}{l}\text { Very Satisfied } \\
\text { - } \text { The Entrance } \\
\text { - } \text { The Ticket Booth } \\
\text { - } \text { Museum's collections } \\
\text { - } \text { The Middle room } \\
\text { - } \text { The Japanese Era room } \\
\text { - } \text { The Toilet } \\
\text { - The Proclamation room } \\
\text { - } \text { The Classic Cars Section }\end{array}$ & 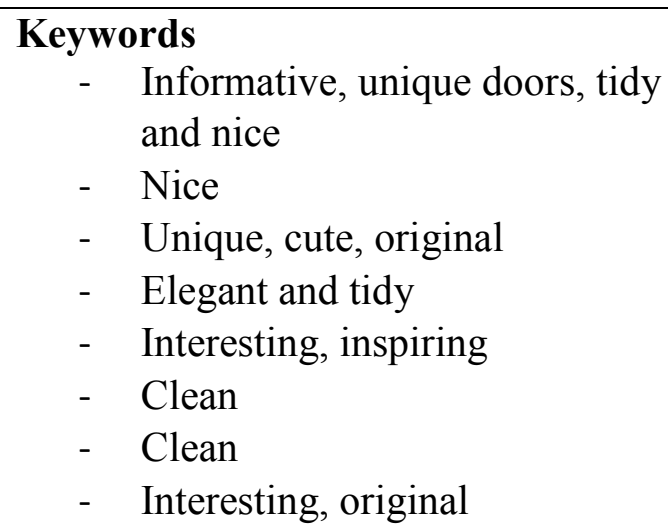 \\
\hline Satistified & Keywords \\
\hline $\begin{array}{ll}\text { - } & \text { Ticket Booth } \\
\text { - } & \text { The Middle room } \\
\text { - } & \text { The Parking Area } \\
\text { - } & \text { The Entrance } \\
\text { - } & \text { The Facade } \\
\text { - } & \text { The Tour guide } \\
\text { - } & \text { The Museum's collections }\end{array}$ & $\begin{array}{ll}\text { - } & \text { Clean and tidy } \\
\text { - } & \text { The nice war map } \\
\text { - } & \text { Clean } \\
\text { - } & \text { Good arrangement and fresh air } \\
\text { - } & \text { Nice } \\
\text { - } & \text { Informative, nice, too fast } \\
\text { - } & \text { Interesting }\end{array}$ \\
\hline Unsatisfied & Keywords \\
\hline - A museum staff & $\begin{array}{l}\text { - Annoying as he interfere on the } \\
\text { tour choice }\end{array}$ \\
\hline
\end{tabular}

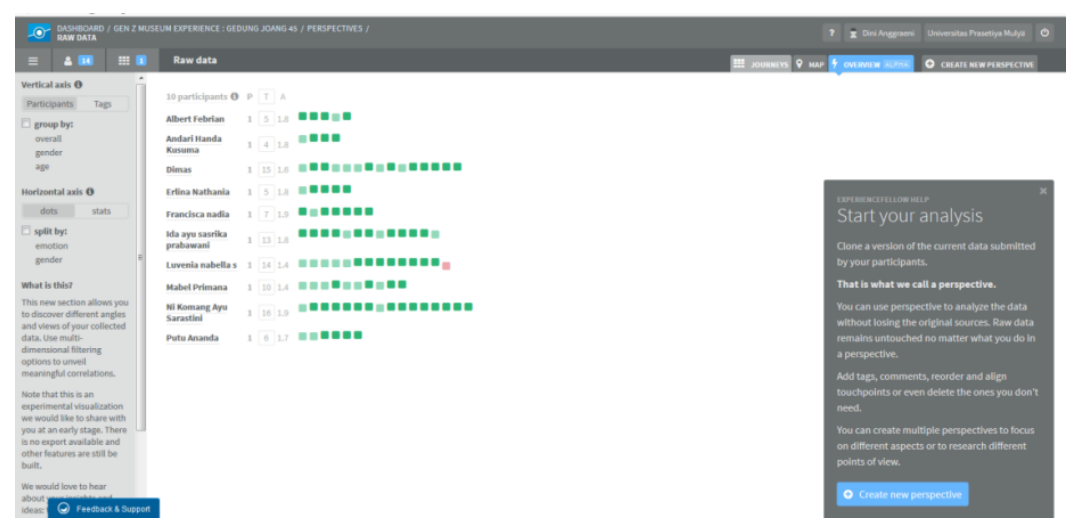

Figure 1. Participant's Overview in Gedung Joang 45 


\subsection{The Formulation of Proclamation Text Museum}

In this museum, students marked 105 touchpoints in 10 journeys. Among the touchpoints, there are 45 "Very Satisfied", 39 "Satisfied", 16 "Neutral", 5 "Unsatisfied" and zero "Very Unsatisfied". The "Very Satisfied" category consisted of the formulation room, the type room, the meeting room, the authentication room, the ticket booth, the actors room, the proclamation room, the after independence room, the cinema, the building facade, and the facility such as ipad, air conditioner and sitting area. The comments for the rooms are clean, tidy and informative. The "Satisfied" category consisted of the same touchpoints as the Very Satisfied category with an addition of the museum building structure. The comments were positive with some room for improvement such as the room lighting which is considered too dark, the ticket booth which would be overloaded if having full visitors. The "Neutral" category consisted of the authentication room, the after indepence, the indepence room, the ticket booth, the actors room, the building facade and the toilet facilities. Their overall comments said that the rooms are simple, but need improvements such as brighter lighting, fresher room temperature, more information and better room arrangement. All of the 5 "Unsatisfied" category consisted of complaints regarding the broken interactive facilities. Table 2 showed their touchpoints and keywords of their specific comments.

Table 2. Touchpoints and Keywords of The Formulation of Proclamation Text Museum

\begin{tabular}{|c|c|}
\hline Categories & Keywords \\
\hline Very Satisfied & Keywords \\
\hline $\begin{array}{l}\text { - } \quad \text { The Formulation room } \\
\text { - } \quad \text { The Typing room } \\
\text { - } \quad \text { The meeting room } \\
\text { - } \quad \text { The Authentication room } \\
\text { - } \quad \text { The ticket booth } \\
\text { - } \quad \text { The Actors room } \\
\text { - } \quad \text { The Proclamation room } \\
\text { - The Post- Indepence room } \\
\text { - The Cinema } \\
\text { - } \quad \text { The Building facade } \\
\text { - } \quad \text { The interactive media } \\
\text { - } \quad \text { Air Conditioner } \\
\text { - The Siting area }\end{array}$ & $\begin{array}{ll}\text { - } & \text { Looks real, tidy, nice, cool, } \\
\text { informative } \\
\text { - } \quad \text { Tidy, fresh,looks real } \\
\text { - } \quad \text { Nice, tidy, clean, informative, historic } \\
\text { - } \quad \text { Clean, informative } \\
\text { - } \quad \text { The ticket price } \\
\text { - } \quad \text { Informative, nice, complete, a bit } \\
\text { humid, too much to read, connected } \\
\text { - } \quad \text { Good, informative, interesting } \\
\text { - } \quad \text { Mamorabilia, well maintained } \\
\text { usefull } \\
\text { - } \quad \text { N/A } \\
\text { - } \quad \text { Nice, ancient, classic } \\
\text { - } \quad \text { N/A } \\
\text { - } \quad \text { Cold } \\
\text { - } \quad \text { N/A }\end{array}$ \\
\hline
\end{tabular}




\section{Satisfied}

- The Formulation room

- $\quad$ The Typing room

- The meeting room

- The Authentication room

- The ticket booth

- The Actors room

- The Proclamation room

- The Post- Independent room

- The Cinema

- The Building facade

\section{Neutral}

- The Authentication room

- The Post-Independent

- The Independence room

- The Ticket booth

- The Actors room

$-$

- The Building facade

- The Toilet

- The Stairs

\section{Unsatisfied}

- Interactive Media

- The Ticket booth

\section{Keywords}

- Nice but a bit dark, informative, impresive

- Nice, cold but a bit dark and spooky, the statues look real, interactive with multimedia

- Cold

- Interactive, informative, could have more information, the separate location make it less historic

- Cheap price, available staff

- Informative

- Story and ambience, informative, a bit hidden but authentic, humid but clean

- Neat, clean, informative, good lighting, small

- Nice staff

- Unique, classic, a bit dark, building date

Keywords

- Nothing special, too dark

- N/A

- Clean but humid

- Dull, too simple

- Not very interesting, humid, broken interactive media

- Dull

- Clean but stinky

- Small and scary

Keywords

- Broken

- Small, should not be merged with security room

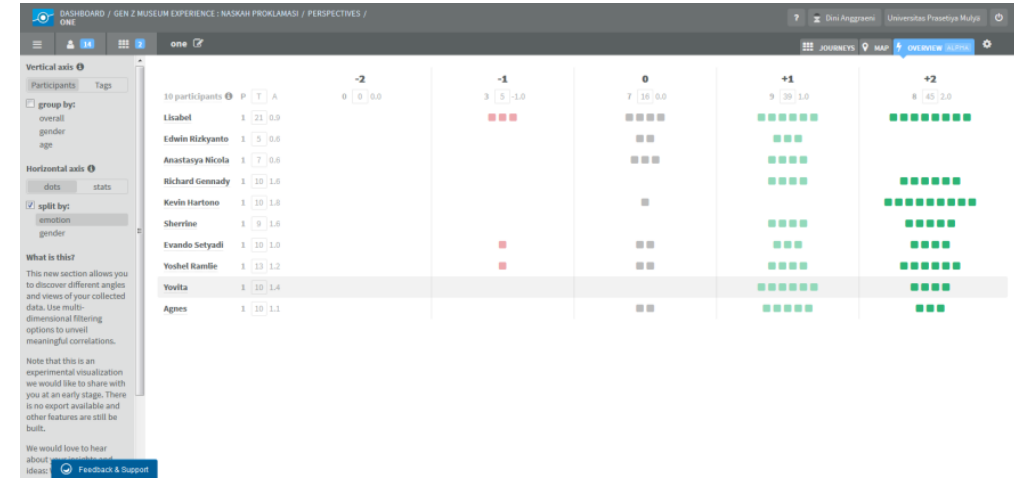

Figure 2. Participant's Overview in The Formulation of Proclamation Text Museum 


\subsection{Puppet Museum}

Puppet Museum has 105 points in 9 journeys. With 37 "Very Satisfied", 43 "Satisfied", 21 Neutral, 3 "Unsatisfied" and 1 "Very Unsatisfied".

The "Very Satisfied" category consist of the Ticketing, the Puppet sections, The Gamelan section, The Mask section, The Stage Performance section, The Entrance and Exit Alley section, The Doll section, The Evil Character section, The JP Coen Tomb

The "Satisfied" category consist of the same sections as the very satisfied with the addition of the Souvenir Shop section.

The "Neutral Category consist of the hallway, the ticket area, the stairs, the foreign puppet, the souvenir section, the puppet history section, and the JP Coen Tomb. Table 3 shows Puppet Museum's touchpoints and keywords of the specific comments.

Table 3. Touchpoints and Keywords of the Puppet Museum

\begin{tabular}{|c|c|}
\hline Categories & Keywords \\
\hline Very Satisfied & Keywords \\
\hline - The Ticket booth & - Friendly staff \\
\hline - $\quad$ The Puppet Sections & $\begin{array}{l}\text { - The puppet condition is well } \\
\text { maintained, informative, variative, }\end{array}$ \\
\hline - The Gamelan Section & interesting \\
\hline - The Mask Section & - Clean, neat, interesting look \\
\hline - The Stage Performance Section & - Interesting, variative \\
\hline - The Entrance & $\begin{array}{l}\text { - Interesting, promoting Indonesian } \\
\text { culture }\end{array}$ \\
\hline - The Exit Alley & - Nice \\
\hline - The Doll Section & - $\quad$ Simple, unique, nice \\
\hline - The Antagonist Character Section & - $\quad$ Surprising \\
\hline - $\quad$ The JP Coen Tomb & - Interesting, good lighting \\
\hline - The Souvenir shop & - Interesting \\
\hline - The Second floor & $-\quad N / A$ \\
\hline & - Spacious, variative, many photo spot \\
\hline
\end{tabular}

\section{Satisfied}

- The Ticket booth

- The Puppet Sections

- The Gamelan Section

- The Mask Section

- The Stage Performance Section

- The Entrance

- The Exit Alley

- The Antagonist Character Section

- The Souvenir Shop Section

\section{Keywords}

- Friendly staff, good service

- Variative, very good but some have less information, good placement

- Nice

- Tidy, well maintained

- Cool, nice, clear, a bit boring

- Esthetic, classic

- Cool, the puppets look real, unique

- Nice shape, good placement

- Variety 


\section{Neutral}

- The Hall Way

- The Ticket Booth

- The Stairs

- The Foreign Puppet Section

- The Ramayana Section

- The Souvenir Section

- The Puppet History Section

- The JP Coen Tomb

\section{Unsatisfied}

- The Puppet History

- Gundala

- The JP Coen Tomb

\section{Very Unsatisfied}

\section{Keywords}

- Modern but humid, variety of puppet

- Nice service but too manual

- The steps are shaky

- More like a decoration

- The light bulb is off

- Uninviting

- Nothing special

- The information of the tomb is in Dutch, no translation

\section{Keywords}

- Too small, uninteresting

- Meaningful but uninteresting look

Keywords

- The Foreign Puppet Section

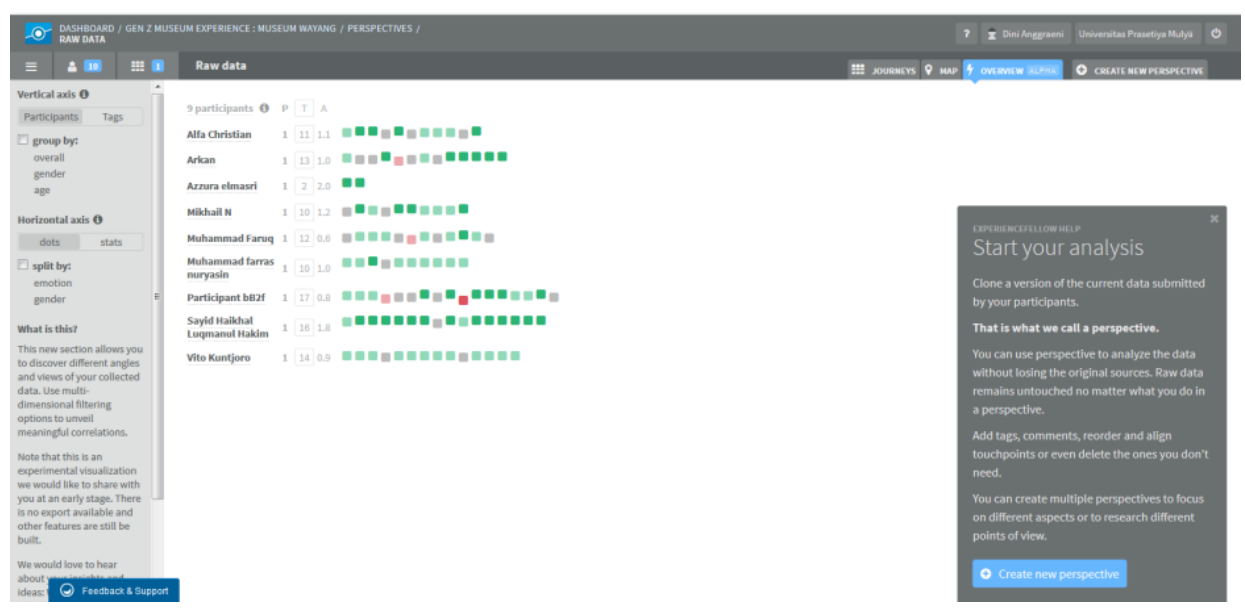

Figure 3. Participant's Overview in The Puppet Museum

\subsection{Ceramic Museum}

Ceramic Museum has 59 touchpoints in 9 journeys: 24 "Very Satisfied", 21 "Satisfied", 8 "Neutral", 3 "Unsatisfied", 0 "Very Unsatisfied".

The "Very Satisfied" category consists of the entrance, the gallway, The Sanggar era, The Painting Collections, Bandung and Yogya Ceramics, European Ceramics, The Museum Inner garden, The Ticket Booth, The Hanuman, The Puppet Section, The Kumbakarna, Cirebon Ceramics, Rahwana and Sinta Section, Traditional painting, Raden Saleh Section, The Chinese Dinasty 
Ceramics. The "Satisfied" category consists of Pre-historic era, Raden Saleh Section, Museum History, The Mooi Indie and Persagi era, The Ticket Booth, The Alley, The Women Statue, The Caligraphy,The Inner Park,The Information Desk, The Traditional Painting, The Museum Map,The Entrance, The Paintings in general, The Museum Certificate. Further more, the "Neutral" category consist of The Mooi Indie and Persagi era, The Relief collection, The Ceramic section, The Museum Certificate, The Japanese Era and The Sanggar Era. In the meantime, the "Unsatisfied" category consist of The Collection Room in general, The Ceramic Section and The Museum Stairs. Table 4 shows Ceramic Museum's touchpoints and keywords of its specific comments.

Table 4. Touchpoints and Keywords of Ceramic Museum

\begin{tabular}{ccl}
\hline \multicolumn{1}{c}{ Categories } & \multicolumn{1}{c}{ Keywords } \\
\hline Very Satisfied & Keywords \\
- The Entrance & - Grandeur \\
- The Hallway & - Cool lighting, impressive paintings \\
- The Sanggar era & - Quite complete collection \\
- The Painting Collections & - Nice and well maintained \\
- Bandung and Yogya Ceramics & - Cool and varied pattern \\
- European Ceramics & - Green, clean, spacious \\
- The Museum Inner garden & - Friendly staff \\
- The Ticket Booth & - N/A \\
- The Hanuman & - N/A \\
- The Puppet Section & - & Huge \\
- The Kumbakarna & - & Cute \\
- Cirebon Cermamics & - & N/A \\
- Rahwana and Sinta Section & - & Interesting \\
- Traditional painting & - & Historic \\
- Raden Saleh Section & - N/A \\
- The Chinese Dinasty Ceramics &
\end{tabular}

\section{Satisfied}

- Pre-historic era

- Raden Saleh Section

- $\quad$ Museum History

- $\quad$ The Mooi Indie and Persagi era

- The Ticket Booth

- The Alley

- The Women Statue

- The Caligraphy

- The Inner Park

\section{Keywords}

- Good space

- Beautiful collections, well maintained, interesting, unspecial

- Interesting but could use some highlight, informative

- Good space, lighting, interesting paintings

- Good service

- Clean and tidy

- Good placement

- Good display

- N/A 
- The Information Desk

- The Traditional Painting

- The Museum Map

- The Entrance

- The Paintings in general

- The Museum Certificate

\section{Neutral}

- The Mooi Indie and Persagi era

- The Relief collection

- The Ceramic section

- The Museum Certificate

- The Japanese Era

- The Sanggar Era

\section{Unsatisfied}

- The Collection Room in general

- The Ceramic Section

- The Museum Stairs
- Friendly staff

- Nothing special

- $\quad \mathrm{N} / \mathrm{A}$

- N/A

- Interesting but hard to understand

- N/A

\section{Keywords}

- The room is dark, hard to see the painting

- The collections are dusty and dirty

- The white wall is boring

- Uninteresting

- Boring

- Nothing special

\section{Keywords}

- Cluttered wall

- Boring

- Steepy

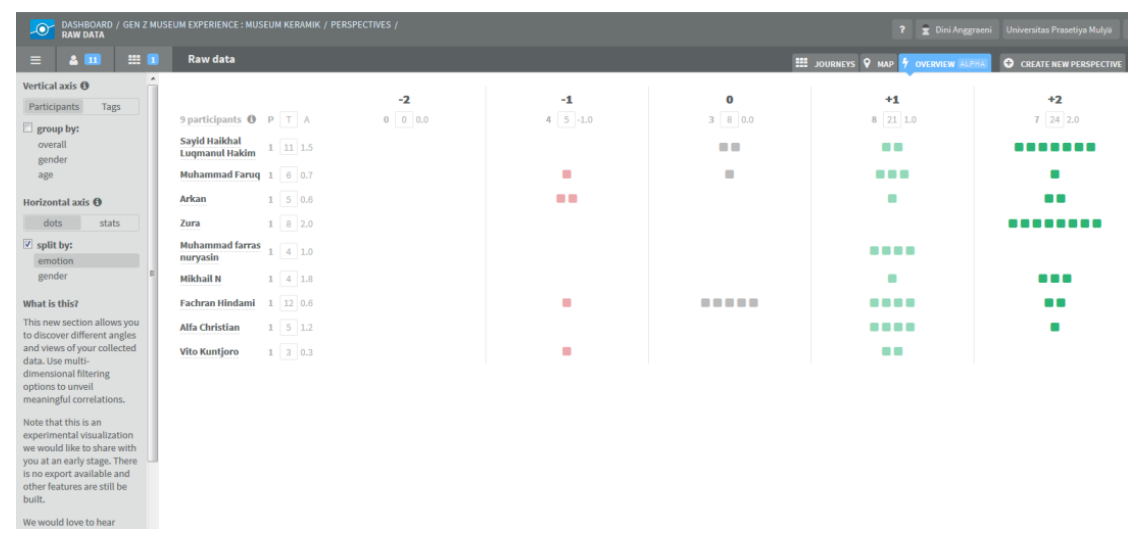

Figure 4. Participant's Overview in Ceramic Museum

\section{E. Discussion}

From the data gathered, there are three common types of museum touchpoints. The first type "Physical and Design" is related to museum's physical appearance such as the building facades, the room arrangement, the rooms and collection condition. The second type "Curatorial" is touchpoints related to museum' collection and information presented at the museum, such as museum collection's range, originality and richness. The third type "Museum Services" related to the services, such as staff availability, hospitality and knowledge. 
In general, the informants gave satisfactory ratings on their touchpoints. However, critiques are also given in the satiscfatory categories. One of the benefit of using the Experience Fellow App is the researcher can dwelve into comments to have a better understanding about the informants' experience

Participants' negative reviews mostly originate from museum services and facilities becoming inaccessible such as non-fuctioning interactive multimedia available at the museum. For this digital-born generation, these services are important to their experience. Furthermore, Gen $\mathrm{Z}$ visitors felt uncomfortable with the museum's high humidity and its lack of proper air conditioning. This suggests that their comfort at the museums are utmost important to Gen Z visitors.

The most appealing aspect for Generation Z visitors related to museum's "Physical \& Design". This category contains both positive and negative reviews, but place a special heart to Gen Z. Future research can further explore Gen Z's need of social media presentation and its connection with museum's "Physical \& Design". The least discussed, but often mentioned touchpoint relates to the need of human interaction. It can be assumed that Gen $\mathrm{Z}$ desires to experience museum more individually and privately. Thus, the presence of a museum tour guide is not necessary, as previously though. They would much appreciate more self-service information and functioning interactive multimedia devices or smart devices.

\section{F. Conclusion}

The study shows that mobile ethnography methodology through technology-based devices and application (i.e. Experience Fellow) can be an innovative and unobtrusive method to evaluate Gen $\mathrm{Z}$ visitors experience. Findings of the study, which were analyzed partially based participant's rating and comments of museum's touchpoints, were able to identify Gen Z three main areas of concern during their visit - Physical \& Design, Curatorial, \& Museum Services. In the future, further analysis, such as semiotics analysis of participants' submitted pictures and videos can be used to discover more enriching findings. As this research was limited to only four museums in Jakarta, future research should add more museums with different curatorial contents and include other attractions in examining Gen $\mathrm{Z}$ behaviors at a destination. The researcher appreciates all four museums cooperativeness with the study. The researcher will share the study's findings with the museum management to ameliorate their current service design in hope of capturing more younger generation of museum attendees. 


\section{REFERENCES}

Andrades, L., and Dimanche, F. (2014). Co-Creation of Experience Value: A Tourist Behavior Approach. In N. Prebensen, J. Chen, \& M. Uysal (Eds.).Creating Experience Value in Tourism (pp. 95-112). London: CABI.

Carey, S., Davidson, L., \& Sahli, M. (2013). Capital City Museums and Tourism Flows: An Empirical Study of The Museum of New Zealand Te Papa Tongarewa. International Journal of TourismResearch, 15(6), 554-569. doi:10.1002/jtr.1874.

Constantine, L. L., \& Lockwood, L. A. (2001). Structure and Style in Use Cases for User Interface Design. In M. Van Harmelen (Ed.). Object Modeling and User Interface Design (pp. 245-280). Boston, MA: Addison-Wesley.

Dimanche, Frederic and Gibbs, Chris. (2016). Improving Service Experiences with Mobile Ethnography: The Case of two Attractions in Toronto.2016). TTRA Canada 2016 Conference. 2. Retrieved from https://scholarworks.umass.edu/ttracanada 2016 conference/2.

Fairview Capital and Partners (2017). Gen Z The Digital Natives. Retrieved from http://www.fairviewcapital.com/application/files/8815/0369/1013/Ge n Z - The Digital Natives Newsletter - August 2017.pdf.

Fardah (2017, October 26). Bright prospect of Indonesian tourism industry.Antaranews.com. Retrieved from https://en.antaranews.com/news/113209/bright-prospect-ofindonesian-tourism-industry.

Gilmore, A. and Rentschler, R. (2002). Changes in Museum Management: a Custodial or Marketing Emphasis?. Journal of Management Development, 21(10),745-760.doi : 10.1108/02621710210448020

Goulding, C. (1999). Interpretation and Presentation in Leask, A. and Yeoman, I. (Eds.). Heritage Visitor Attractions: An Operations Management Perspective, Cassell, London, pp. 54-67.

ICOM (2007). Museum Definition. Retrieved from http://archives.icom.museum/definition.html

Kirshenblatt-Gimblett, B. (1998). Destination culture: Tourism, museums, and heritage. University of California Press.

Muscat, M., Muskat, B., Zehrer, A., and Johns, R. (2013). Generation Y: evaluating services experiences through mobile ethnography. Tourism Review, 68(3), 55-71. doi: 10.1108/TR-02-2013-0007

Prensky, M. (2001). Digital natives, digital Immigrants. On the Horizon. 9(5), 1-6.

Stickdorn, M., \& Frischhut, B. (Eds.) (2012). Service Design and Tourism. Norderstedt, Germany: Books on Demand.

Salam, F., Ingkadijaya, R., \& Hermantoro, H. (2018). Strategies to Develop Sawahlunto Old City in West Sumatera as Tourism Destination. TRJ Tourism Research Journal, 2(2), 78 - 93. doi:10.30647/trj.v2i2.45 
Salvatore Monaco (2018). Tourism and The New Generations: Emerging Trends and Social Implications in Italy. Journal of Tourism Futures, 4(1), 7-15. doi :10.1108/JTF-12-2017-0053

Spillane, James J. (1987). Ekonomi Pariwisata, Sejarah dan Prospeknya. Kanisius.

Stickdorn, M., Frischhut, B., and Schmid, J. (2014). Mobile Ethnography - a pioneering research approach for customer-centered destination management. Tourism Analysis, 19(4), 494-504.

Stylianou-Lambert, T. (2011). Gazing from Home: Cultural Tourism and Art Museums. Annals of Tourism Research, 38(2), 403-421. doi:10.1016/j.annals.2010.09.001 